\title{
Equality: The Power and Limits of the Law
}

Feminism and Sexual Equality. By Zillah R. Eisenstein.* New York: Monthly Review Press, 1984. Pp. 266. Paper $\$ 10.00$.

\section{Sylvia A. Law†}

Feminist theory provides a rich source of insight into the power and limits of the law in molding social relations. The feminist critique touches every institution of human life, casting new light on the ways in which we experience ourselves and the world. ${ }^{1}$ Zillah $\mathbf{R}$. Eisenstein provides an eloquent contribution to feminist theory. ${ }^{2}$ She contrasts feminism with the range of other contemporary American political thought-liberalism, conservatism, neoconservatism, the Old and New Right. She offers a trenchant critique of the contemporary revision of and reaction to the feminist challenge to a sexist society, analyzes recent developments in electoral politics as largely a response to the potentially radical implications of mainstream feminist claims, and articulates an affirmative vision of social relations that will interest anyone who cares about a better world, not just for women, but for people and families in general. The first half of this review examines Eisenstein's central points: her vision of feminism, her critique of contemporary revisions of feminism, and the complex relationships between feminism and other dominant political and economic ideologies. The second half of the review attempts to make the abstractions of these competing world views more concrete by applying them to one specific social problem-the care of the old.

\footnotetext{
* Professor of Politics, Ithaca College.
}

$\dagger$ Professor of Law, New York University School of Law and MacArthur Prize Fellow. Martha Minow, Elizabeth Schneider and Barry Ensminger generously shared encouragement, ideas and their scarce time.

1. See generally Women's RTS. L. ReP. and Harv. Women's L.J. Somewhat more concretely, see C. Mackinnon, Sexual Harassment of Working Women: A Case of Sex DiscriminaTION (1979); Estrich, Rape, 95 YAl.E L.J. 1087 (1986); Frug, Securing Job Equality for Women: Labor Market Hostility to Working Mothers, 59 B.U.L. REv. 55 (1979); Olsen, The Family and the Market: A Study of Ideology and Legal Reform, 96 Harv. L. REv. 1497 (1983).

2. Z. Eisknst'iIn, Feminism and Sexual. Equality (1984) (hereinafter cited by page number only]. 


\section{A Statement of Feminism}

Although Eisenstein's book is dense and expansive, she keeps clear focus on several core insights which together constitute the feminist challenge to patriarchy. Such clarity is difficult to achieve, because the central ideas of feminism are each complex and, at a superficial level, sometimes appear to conflict. Briefly, these are the six complex concepts that Eisenstein keeps in the air and juggles in intricate patterns:

Individual women's steady demands for equality and liberty appeal to ideals of justice shared across the political spectrum and have serious potential for radical social change. ${ }^{3}$

Gender is socially constructed, i.e., the culture, the law, and the material relationships within and between the family and marketplace all give deep meaning to gender. ${ }^{4}$

A core aspect of the social construction of gender is that culture and law ${ }^{5}$ assign women responsibility for the socially and economically necessary work of nurturing, childrearing, managing household consumption, and providing domestic labor. ${ }^{8}$

Although the meaning of gender is socially defined, "identity is both a biological, material reality and simultaneously a part of a sexgendered system;" the female body-distinguished by its capacity for childbearing-must be central to any feminist political theory. ${ }^{7}$

The state and the law institutionalize male power by mystifying the division between public and private life as one of "natural" sexual difference, enforcing the separation of public and private life and with it the distinctness of male and female existence. ${ }^{8}$

Although the patriarchal character of the state and the law requires feminists who seek to use state power as a vehicle for social change to exercise caution, struggles within the law are nonetheless

3. P. 12 .

4. Eisenstein argues that women are a sexual class, "because what they do as women-the activities they are responsible for in society, the labor that they perform-is essential and necessary to the operation of society as it presently exists." P. 146 (emphasis in original). In this sense, women are a class within a traditional Marxist framework because of their relationship to the means of production. In addition, women are a sexual class because "the biological female is transformed through a series of political relations into a woman, differentiated from man." P. 150. Finally, women are a sexual class because they are able to develop and act upon a sexual class consciousness. Id. "They become a class in actual struggle against patriarchal privilege." P. 154.

5. P. 108 .

6. P. 146.

7. P. 216. "What does sexual equality mean and how does one try to create truly egalitarian relations while recognizing the biological differences constituted by women's ability to bear children?" P. 206.

8. P. 92. See also D. Polan, Toward a Theory of Law and Patriarchy, in ThE Politics of LAw: A PROGRessive CRITIQUe 294 (D. Kairys ed. 1982); J. Rifkin, Toward a Theory of Law and Patriarchy, in Marxism and the Law 297 (P. Beirne \& R. Quinney eds. 1982). 


\section{Equality}

important for feminists seeking to achieve both material and ideological change. ${ }^{\ominus}$

The claim that the law should treat women and men as individuals, not as members of a sexually determined class, necessarily denies that gender differences are natural or immutable. ${ }^{10}$ Our concepts of gender, and particularly our ideas about motherhood and sexuality, cast man as strong, woman subservient; man as irresponsible for family care, woman as nurturant; man as sexually aggressive, and woman as victim, whether virgin or whore. In Simone de Beauvoir's classic words, "One is not born, but rather becomes, a woman."11 Yet although feminism begins with the basic claim that these gender differences are not natural, and liberty and equality should extend to women, feminism has, Eisenstein argues, implications far more radical than simply extending liberal rights to women. The social construction of gender shapes not only our ideas about who we are, but the social and economic arrangements that determine the texture of our daily lives. Under the normal prevailing arrangements of market and family, the price a woman pays for the warmth, support and legitimacy of family is to subordinate her capacity to achieve and contribute in the public world to the nurturing needs of children, parents and men. ${ }^{12}$ Further, because the structure of the law and the state differentiates between the public and private, the market and home, claims to liberty and equality have value only in this traditional male world of market and public life. The morality of motherhood is one of giving, connection and self-sacrifice, while the morality of the male world is one of achievement, autonomy and self-interest. ${ }^{13}$ The prevailing social construction of gender means that normal economic relations systematically deny the worth of traditional women's work in the home and wage market. ${ }^{14}$

Thus individual women's claims for formal equality in the traditional male world are radical because the working mother embodies the contradiction between the liberal promise of equality in public and market life and the reality that our liberal society depends upon the unpaid work performed by women in the home. But individual claims for formal equality alone are insufficient to achieve either liberty or equality. Within the context of socially constructed gender, rights of formal equality can only

9. Pp. 99-100.

10. Remember Rosa Parks? If not, see M.L. King, Stride Toward Freedom (1958). Betty Friedan, whose recent work Eisenstein describes and critiques, is another excellent case study of a woman who transcended her social condition. Pp. 189-200.

11. S. DE Brauvotr, The Second Sex 267 (1957).

12. P. 37.

13. P. 34 .

14. For my discussion of these issues, see Law, Woman, Work, Welfare, and the Preservation of Patriarchy, 131 U. PA. L. Rev. 1249, 1282-1335 (1983). 
help the exceptional individual who, in some limited respect, transcends the pervasive constraints of social construction. Individual claims do not dismantle the social meaning of gender. Indeed, insofar as such claims aid women seeking access to traditional male roles on male terms, traditional female virtues are implicitly devalued further. ${ }^{15}$ Recognizing formal rights to individual equality, without dismantling the institutional relations supporting the social construction of gender, can in fact exacerbate the vulnerability of women. ${ }^{16}$

Eisenstein argues that liberalism, capitalism, and patriarchy are tightly interdependent. All assume a sharp division between altruism and competition, home and market, private and public, economy and state, passion and reason, women and men. If, as feminists claim, the distinctions between women and men are suspect, then perhaps so are the other distinctions. ${ }^{17}$ To challenge gender inequality is to challenge the institutions it supports. As women enter the wage market and encounter sexual bias, including the expectation that they will continue to bear the responsibilities for home and children, they discover that our social arrangements cannot fulfill promises of individual equality without profound structural change.

Despite the limitations of formal liberal rights, struggles within the law are an important part of the process of challenging patriarchal privilege. They heighten the contradiction between the law's promise of neutrality and equality and the reality that liberalism and capitalism depend on patriarchy. Further, apart from its ideological function, the law also "structures choices, options, and so on, and in this sense has a real, material presence that at one and the same time mystifies other concrete relations of power."18 For example, the law determines whether abortion is prosecuted as a crime or protected as a constitutional right. Women's claim to

15. See Note, Toward a Redefinition of Sexual Equality, 95 HaRv. L. Rev. 487 (1981).

16. For example, courts often limit alimony or support to women who have worked in the home for many years, assuming that when marriage ends, the woman can support herself. $\Lambda$ Florida court, denying alimony to a homemaker of 21 years, said "In this day and time, women are as well educated and trained in the arts, sciences, and professions as are their male counterparts." Beard v. Beard, 262 So. 2d 269, 272 (Fla. Dist. Ct. App. 1972).

More generally, see L. Wertzman, The Divorce Revolution: The Unexpected Social. and EConomic: Consequencies for Women and ChILdren in AMERICA (1985). Using Bureau of Labor Statistics data, Weitzman shows that following divorce the standard of living of men improves by $42 \%$, while that of women declines by $73 \%$, and argues that the movement to no-fault divorce has disadvantaged women. Some, such as Schrag, Book Review, ThE NAtion, Dec. 7, 1985, at 620, characterize these facts as "one of the great embarrassments of the modern feminist movement." This of course ignores that most divorced women have always been disadvantaged economically and that feminists were only one small ambivalent voice supporting the movement away from fault-based divorce. See Babcock, Cases and Materials on Women and the LAW 261-88 (1974); see also Fineman, Implementing Equality: Ideology, Contradiction, and Social Change, 1983 WiS. L. REv. 789.

17. P. 12 .

18. P. 99. 
reproductive liberty is critical materially and ideologically; to claim reproductive freedom is to reject social norms that label women as victims, virgins or self-sacrificing mothers. ${ }^{19}$ Similarly, the state controls the terms on which social forms of child care or nurturing services are available, and thus profoundly shapes women's lives.

Combining the threads of these six analytic skeins, Eisenstein weaves two rich tapestries. In the first she criticizes other feminists who would cabin the radical implications of the forces they have helped to unleash by dropping one or another of the essential elements of the feminist challenge to patriarchy. In the second she analyzes the recent ascendence of New Right and neoconservative power in Washington, arguing that these developments confirm the power of the feminist challenge to patriarchy.

\section{FEMINIST ReVISIONISM}

Sexual equality challenges the social meaning of gender and requires radical change in our legal and economic order. Radical change is both scary and difficult to achieve. Today, many feminists feel discouraged and overwhelmed by attempts to seize opportunities traditionally reserved for men while continuing to bear the responsibilities traditionally assigned to women. Some respond by blaming feminism for extending false promises. Others suggest revisions of core feminist claims.

Eisenstein identifies two major strains of feminist revisionism. The first claims, in various ways, that perceived sex-based differences are natural and inherent, rather than socially constructed. The second denies the radical nature of feminism by characterizing the challenge of sexual equality as a simple matter of individual claims to fair treatment and choice. Eisenstein helps us to evaluate these revisions, urging us to reject their flaws and to reaffirm our demand for meaningful equality.

Some feminists, observing that formal equality has failed to empower women and has implicitly devalued traditional women's work and lives, assert that women and men are naturally, essentially different, and that the feminist task should be to enhance traditional women's roles. ${ }^{20} \mathrm{Al}$ -

19. P. 34.

20. For example, in 1964 Alice Rossi was committed to a socially androgynous conception of the roles of men and women, but today she argues that "biological conventions shape what is learned, and that there are differences in the ease with which the sexes can learn certain things." Compare Rossi, Equality Between the Sexes: An Immodest Proposal, 93 Daedalus 607, 608 (1964) with Rossi, A Biosocial Perspective on Parenting, 106 Daedalus 1, 4 (1977) (footnote omitted). Others, such as Susan Griffin and Mary Daly, describe a biological, almost mystical, female essence, which they claim is superior. S. Griffin, Woman and Nature: The Roaring Inside Her (1978); M. Daly, Gyn/Ecology: The Metaethics of Radical Feminism (1979) (discussed in Z. EisenSTEIN at 221-25). Jean Elshtain also affirms essential, biological, sex-based differences. Elshtain, Against Androgeny, Trios, Spring 1978 (discussed in Z. Eisenstein at 215-16). See also J. Elshtain, Public Man, Privatr: Woman: Woman in Social and Polmtical Thought (1981). 
though the reasons for this development are understandable, Eisenstein urges us to hold fast to the insight that gender differences are socially constructed. A feminist affirmation that women and men are naturally and essentially different seriously undercuts the individual claim to formal equality. But more important, blurring the differences between biology and culture disguises the economic and political constructs that give meaning to gender.

The impulse to affirm that some gender differences are natural is particularly strong in relation to motherhood and sexuality. Again, this is understandable. There is, of course, a material reality to the biological difference between the sexes in relation to reproduction. Yet the social construction of sexuality and motherhood are core mechanisms by which patriarchal culture attaches social meaning to gender. Adrienne Rich observes that "[ $t$ ]he body has been made so problematic for women that it has often seemed easier to shrug it off and travel as a disembodied spirit."21 Eisenstein simultaneously affirms that the biological capacity for reproduction distinguishes men from women, while seeking to dismantle oppressive constructions of the meaning of this difference. ${ }^{22}$ She challenges us to develop a politics that neither denies biology nor uses it to justify prevailing social relations.

Eisenstein argues that motherhood is political, as well as biological. She criticizes those-across the political spectrum-who claim that "mothering" comes naturally to women, as well as those, such as Betty Friedan, who treat motherhood solely as a matter of individual choice and underestimate the social arrangements that constrain choice. ${ }^{23}$

Similarly, some feminists respond to the political and personal dangers of sexuality by rejecting the notion that feminism is concerned, in a central way, with sexuality. ${ }^{24}$ Eisenstein critiques others who regard sexuality as critical to gender hierarchy, but who describe gender-based differ-

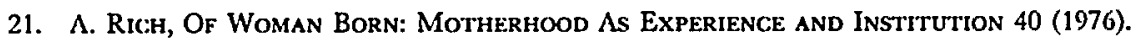

22. For my discussion of these issues, see Law, Rethinking Sex and the Constitution, $132 \mathrm{U}$. PA. L. REv. 955 (1984).

23. "In The Feminine Mystique Friedan argued for women's right freely to reject housewifery (and motherhood) and to enter the market. In The Second Stage she argues that women should have the right to be in the market and to choose motherhood as well. The theme-the individual's freedom of choice-remains the same." P. 199. Friedan says, "I am for life and for family . . . . I am not for abortion-I am for the choice to have children." B. Frifdan, The Second STage 107 (1981) (emphasis omitted). Eisenstein asks, "[g]iven the government's lack of commitment to child care, the rise of teenage pregnancies, the increasing number of woman-headed single-parent families, and the dismantling of social welfare programs, what does Friedan think freedom of choice means?" P. 202.

24. For example, Jean Elshtain "criticizes feminism for its supposed commitment to androgyny, its flight from feeling, its endless selfishness." P. 213 (footnote omitted).

In recent years Betty Friedan has argued against connecting feminist politics with gay liberation, saying, "it twists the focus to sexual politics... [I]t gets mixed up with the reaction against the female role, and threatens people who feel sex should be private and are mixed up about it themselves." B. Frikidan, supra note 23, at 319. 


\section{Equality}

ences in relation to sexuality as essential, biological differences between women and men. Andrea Dworkin, for example, says that " $[t]$ he immutable self of the male boils down to an utterly unselfconscious parasitism,"25 and that "[t]error issues forth from the male, illuminates his essential nature and his basic purpose."28 Women, by contrast, "are booty, along with gold and jewels and territory and raw materials."27 Somewhat more subtly, Catharine MacKinnon claims that "male morality sees that which maintains its power as good, that which undermines or qualifies it or questions its absoluteness as evil,",28 and argues that "[w]omen and men are divided by gender, made into the sexes as we know them, by the social requirements of heterosexuality, which institutionalizes male sexual dominance and female sexual submission. If this is true, sexuality is the linchpin of gender inequality." 29

Eisenstein retorts: "[I]t is not helpful to set up a causal relation between sexuality and gender."30 Both are constructed out of series of social relations that define the other's meanings. To assume that "there is such a thing as sex, or sexuality (in some natural-presocial-form)" avoids the true issue of how both sexuality and gender are constructed..$^{31}$

Authentic communication about sex is enormously difficult. Our understanding of sexuality - the social and individual influences on choice of sex object, sources of lust, and connections between passion and relationship-is breathtakingly primitive. The feminist and gay effort to explore, intellectually and experientially, the gendered social meaning attached to sexuality provides a weapon for those who would defend a status quo that is puritanical, as well as patriarchal..$^{\mathbf{2 2}}$

The second major form of feminist revisionism is the tendency to undercut the radical potential of feminism's challenge to patriarchy by asserting that women are capable of achieving liberty or equality one by one. This view characterizes women's claims for equality as matters of individual choice, without acknowledging, indeed, even denying, that "patriarchy, capitalism, and racism impose constraints on individual freedom."33 For

\footnotetext{
25. A. Dworkin, Pornography: Men Possessing Women 13 (1981).

26. Id. at 16.

27. Id.

28. MacKinnon, Not a Moral Issue, 2 YAle L. \& Pol'y Rev. 501, 511 (1984).

29. MacKinnon, Feminism, Marxism, Method, and the State: An Agenda for Theory, 7 Signs 515, 533 (1982) (footnote omitted).

30. P. 152.

31. Id. (emphasis in original).

32. See A. Echols, The Taming of the Id: Feminist Sexual Politics, 1968-83, in Pleasure AND Danger: Exploring Female Sexuality 50, 63-65 (C. Vance ed. 1984).

33. P. 195.
} 
example, Betty Friedan has said, “'[o]ur own self-denigration of ourselves as women and perhaps our own fears are the main problem.'",34

Feminists who embrace this individualistic approach share Jean Elshtain's belief that "equality of opportunity and equality of treatment are ultimately incompatible."ss But those feminists who would limit women's demands to equality of opportunity do not recognize that so much must be remade to make opportunities really equal, including the very standards by which results are judged. Feminists, and the civil rights movement generally, challenge supposed meritocratic standards that are defined in white, male terms. We can applaud the notion that excellence, hard work and diligence deserve reward and recognition, yet condemn standards of distinction that systematically exclude women and people of color. We need a concept of equality that values nurturing and relationship, not as inherent differences between women and men, but as human strengths that have been devalued by being removed from the market and assigned to people removed from the market. To challenge allegedly neutral standards of quality for neglecting virtues of care and connection is not to deny the value of merit-based reward, but to use a richer concept of worth.

In sum, Eisenstein provides a powerful account of feminism, incorporating a traditional liberal respect for individual rights with an understanding that patriarchy denies equality, not simply on an individual basis, but systematically through the social construction of gender.

\section{NEOPATRIARCHY}

Eisenstein's analysis of New Right and neoconservative ideology helps us to understand that the fury of conservative reaction to feminism does not show we are on the wrong track or have "gone too far," but confirms the radical implications of women's basic claims for liberty and equality. There is broad support for these claims. If change at times seems slow in coming, it is not because of the strategic or intellectual failings of feminists, but because a powerful minority has mobilized energetically to preserve its privilege.

The New Right and neoconservatives have shared political power in Washington for several years. Their agenda is obviously complex. Eisenstein takes issue with progressive analysts who explain the Reagan Administration's assault on working people and the poor solely in class terms, ${ }^{36}$ arguing that the Administration also seeks to restabilize patri-

34. Id. (quoting B. Friedan, It Changed My Life 103 (1977)) (emphasis added) (footnote omitted); see also supra note 23.

35. Elshtain, The Feminist Movement and the Question of Equality, 7 PoLrTy 452, 473 (1975).

36. See, e.g., F. Pivan \& R. Cloward, The New Class War: Reagan's attack on the 
archy by making it more difficult for women and children to survive without a man.

The New Right shares with feminism the understanding that the patriarchal family and prevailing economic structures are tightly related. Both understand that the paid labor market is structured on the assumption that workers, i.e. men, are supported by family, i.e. women, who meet their daily emotional and material needs, as well as care for the vulnerable young and old. Both perceive that the exponential increase in the number of married women and mothers in the wage market poses a profound threat to these basic arrangements.

Even people who consider it "natural" that women do the unpaid work in the home hold that in the marketplace "[p]eople are supposedly individuals, not members of a sexual class. Hard work is supposed to be rewarded. When the married woman enters the market, she embodies a contradiction. As a worker she is supposedly an individual, and as a married woman she is a member of a sexual class." ${ }^{\text {"37 }}$ As these women begin to recognize the sexual bias of the marketplace and continue to bear the responsibilities of housework and child care as well, they discover that society cannot deliver on its promise of equality or even equal rights for women. ${ }^{38}$

The New Right's response to this is contradictory. They affirm that equality of opportunity exists for anyone willing to work hard, yet at the same time they insist that men and women are naturally different. Some members of the New Right would reject norms of sex-based equality even in the marketplace. George Gilder, for example, argues that even though sex-based differences are natural and fundamental, social policy must reinforce them to preserve the traditional family. Men must be given preference in wage labor and public life to reinforce male dominance in the family and familial dependence upon them. The patriarchal family, moreover, is essential to curb men's natural tendencies toward aggression. ${ }^{39}$ The New Right also rejects liberty of sexuality and sexual preference "as breeding sexual license and hedonism and a breakdown of the (heterosexual, monogamous) family life." 40 The New Right's economic program seeks, in part, to reconstruct the patriarchal family by alleviating the twin burdens of taxes and inflation, thereby freeing married women from the need to earn a "second" income."1

\footnotetext{
Wet.fare: Statte and Its Consequences (1982) (discussed in Z. Eisenstein at 125).

37. P. 51 .

38. P. 41 .

39. P. 55. Gilder says, "the movement is striking at the Achilles' heel of civilized society: the role of the male." G. Git.drir, Stxual. Suicine 193-94 (1973).

40. P. 56.

41. P. 46 .
} 
The New Right also shares with feminism a rejection of the liberal dichotomy between public and private spheres, with sexuality and family defined as "private" matters properly distinct from the "public" concerns of political life. In its place the New Right promotes a culturally and legally enforced ideal of the patriarchal family. But the feminist challenge to the public/private dichotomy is more complex. Feminists criticize the state's role in patriarchy, yet at the same time insist that collective responses are needed to protect vulnerable people and to organize the work that the patriarchal culture has traditionally assigned to women. Like feminism, the New Right is radically subversive to the modern liberal state because it "demystifies the place of sex and family life within the political order by challenging the private/public split on these issues."

Neoconservatives share the New Right's distress at the feminist challenge to existing arrangements but are less willing to use direct state power to preserve the patriarchal family. Instead, neoconservatives seek to save liberalism from the "excesses" of equality and liberty. ${ }^{4}$ "[T] of liberalism is not merely a political crisis, it is also a cultural problem. The individual, which is the root concern of liberalism, has begun to be hedonistically centered on himself, or more likely herself . . . [, representing] the troublesome extension of liberal individualism." ${ }^{24}$ To save us from these excesses, neoconservatives would reject the changes in social arrangements that make liberty and equality possible. For example, neoconservatives would dismantle the social programs of the New Society, which, they argue, create unreasonable expectations and weaken the "mediating structures"-family, church and community-that stand between individual and state. ${ }^{45}$ Neoconservatives ignore the fact that these mediating structures run on the voluntary labor of women. They condemn affirmative action, which they characterize as demanding equal results for people of unequal merit. Neoconservatives believe that a race in and of itself requires winners and losers, and "the problem is that everyone today claims the right to win." ket and political system are structured to favor elite, white men, who have a team, i.e., the family and old boy network, in the pit to pass water and cheer them on.

42. P. 82 .

43. P. 62. Among the major neoconservative works that Eisenstein critiques are: AMERICAN ENterprise Institute for Public Policy Research, Meeting Human Needs (J. Meyer ed. 1982); D. Bell., The Cultural Contradictions of Capitalism (1975); I. Kristol, Two Chefrs for Capitalism (1978); P. Steinfeis, The Neoconservatives: The Men Who Are Changing America's Politics (1979).

44. P. 78.

45. P. 69 .

46. P. 63. 
In addition, many neoconservatives now affirm that gender differences are natural. ${ }^{47}$ Midge Decter, for example, argues that women need heterosexual marriage, not solely for economic reasons, but to put "a lid on their freedom." ${ }^{48}$ She explains, "[f]or the middle-class woman her opportunities to participate in the world beyond household-to educate herself, limit her family, go to work, and to an unprecedented extent make her life-have left her in a sometimes nearly overwhelming state of uncertainty." 48

The Reagan strategy, while causing enormous pain to millions of people, cannot reconstruct the patriarchal family. Too much has changed, both in the economy and in the aspirations of women and men. The neoconservative effort to preserve the patriarchal family confuses cause and effect. Neoconservatives assert that the welfare state has destroyed traditional family and wage labor relationships, when in fact profound changes in family and work have created both the need and the desire for dual wage-earning families and welfare state programs.

Jobs that allow a single wage-earner to support a patriarchal family are no longer available for most people due to structural changes in the labor force, principally the massive shift of jobs from unionized industrial work to nonunionized, low paid service and retail-trade work. ${ }^{50}$ "[M]ultinationals have shifted amortization funds overseas to the strategic handful of export platforms whose political regimes maintain a combination of literate skilled labour with low wages . . ." Os1 Our society has become increasingly dichotomized between the wealthy and the poor. The middle class is vanishing. These changes in the economy prevent a return to the patriarchal home with daddy in the marketplace and mommy baking cookies for the kids and gramps, even were this return thought desirable.

Most people, however, do not see the patriarchal family as optimal. Certainly families, and particularly women, struggling with the dual burdens of maintaining a career and a family, understand the acute need to change prevailing arrangements. Today most women do not want a lifetime of unpaid work in the home and economic dependence on a man. Most women do not want this for themselves and certainly not for their

47. P. 80 .

48. P. 78.

49. M. Dhcirre, The New Chasitty and Other Arguments Against Women's LiberaTION 51 (1972).

50. P. 49.

51. Davis, The Political Economy of Late-Imperial America, NEw LEFT REv., Jan.-Feb. 1984, at 6, 15-16. See also Jeffries \& McGahey, Equity, Growth and Socioeconomic Change: AntiDiscrimination Policy in an Era of Economic Transformation, 13 N.Y.U. REv. L. \& Soc. ChangE 233 (1985) (general discussion of effects of U.S. socioeconomic changes on antidiscrimination efforts). 
daughters. Indeed, most men do not want a lifetime burden of supporting a dependent, patriarchal family. ${ }^{62}$

\section{Growing Old In America: Methodology and Analysis APPLIED}

Consider-in very general terms-how the various ideologies Eisenstein describes can be employed to illuminate one concrete problem. The American population is getting old. Since 1900, the proportion of the population over 65 has grown from $4 \%$ to $11 \%$; if present trends continue, $22 \%$ of the population will be over 65 by $2050 .{ }^{53}$ Assuming zero population growth, the proportion of older people in the non-working population will increase from approximately $25 \%$ in 1980 to about $40 \%$ by $2025 .{ }^{54}$ While care of the old is of course a timeless problem, our current demographic patterns presage an era when large numbers of older people will be dependent upon a younger generation that is relatively much smaller. In political terms, it is probably even more relevant that the Baby Boomers, the post World War II population cohort who have made waves as they have passed through various stages of life, will soon reach the age when disability and death of parents and contemporaries are increasingly common.

At any one time, about one third of all people over age 65 require some regular form of support services. ${ }^{65}$ Older people experience great uncertainty and anxiety about their ability to obtain services if and when needed. The overwhelming majority of older people are women, with this percentage increasing with age. ${ }^{.8}$

The care of the old, like the care of the young, is performed by women. Our patriarchal culture has created in women a deeply internalized sense of personal responsibility to care for friends and families in times of need. This "feminine" virtue is both a tremendous strength and a burden. Women spend much time caring for elderly family members, friends and neighbors: giving personal care, shopping and running errands, maintain-

52. See B. Ehrenreich, The Hearts of Men: American Dreams and the Flight from COMMTTMENT (1983).

53. U.S. Bureau of the Census, Population Estimates and Projections, Current PopUlation Reports, Series P-25, No. 922 (Oct. 1982), at 1.

54. Shanas \& Hauser, Zero Population Growth and the Family Life of Old People, $30 \mathrm{~J}$. Soc. Issurs 79, 82-83 (1974).

55. Brody, Women in the Middle and Family Help to Older People, 21 The Gerontologist 471, 472 (1981). See Taub, From Parental Leaves to Nurturing Leaves, 13 N.Y.U. REv. L. \& Soc. Change. 381 (1985).

56. See the data collected in Feldblum, Home Health Care for the Elderly: Programs, Problems, and Potentials, 22 HARv. J. Leg. 193, 195 nn.12-14 (1985). Feldblum's article, and Taub, supra note 55, detail excellent liberal feminist programs for providing nurturing care for old people. Both are utopian in assuming a political will to increase greatly the social resources devoted to work traditionally done by women "volunteers." 
ing households and finances, coordinating and monitoring services from other sources, and filling in when other care arrangements break down. ${ }^{57}$ In addition, women also constitute the vast majority of paid workers who care for the old, either at home or in institutions. ${ }^{58}$ In terms of pay and status, the work these women perform shares the bottom of the occupational hierarchy with the work of women who care for children. ${ }^{.9}$ "Caregivers" is a euphemism for women.

Providing care for old people is costly. Individuals bearing this responsibility do so at high personal cost, either financially or in terms of lost opportunities to do other forms of work. ${ }^{\text {o0 }}$ Although we devote substantial public resources to care for the old, ${ }^{61}$ services fall far short of need. ${ }^{62}$

Both the New Right and the neoconservatives oppose public funding for programs supporting or supplementing family-based services, both because such programs undermine "voluntary" patriarchal structures and because they cost money, inescapably requiring either higher taxes or reductions in defense spending. They view the care of elderly people as the responsibility of family, church, and community organizations. For example, a 1980 House report on the needs of the aged decries the decrease in women's participation in voluntary community service, arguing that "a shift back to such a natural system as the voluntary sector is in order." The report predicted that the "rate of increase in the proportion of women working outside the home . . . would slacken." proved wrong. Women continue to need and seek paid work; the status and support for voluntary work have not increased. For reasons suggested above, neither the neoconservatives' wistful desire to reinvigorate the patriarchal family, nor the New Right's more aggressive program to do so, is likely to succeed.

As the economic gap between the rich and the poor grows, it is possible

57. Brody, supra note 55, at 474.

58. Offick of Human Div. Admin. on Aging, U.S. Dept. of Health, Educ., \& Welfare, Pub. No. 77-20086, Homemaker-Home Heai.th Aide Skrvices 15 (1977).

59. M. WIIT \& P. MAHERnY, WOMEN's WORK: UP FROM .878, REPORT ON THE DOT RESFarc:H Projec:I 11 (1975), discussed in Law, supra note 14, at 1307-08.

60 . Taub, supra note 55 , at 387 .

61. In 1985 the three largest federal domestic spending programs were Social Security, Medicare, Part $\Lambda$ (the hospital insurance program for the aged and disabled) and Medicare, Part B (the physician insurance program for the aged and disabled). Staff of Senate Special Comm. ON Aging, 98th Conci., 2D Skss., Medicare: Paying the Physician-History, Issues, and Options (Comm. Print 1984).

Medicaid-the state/federal program providing health insurance to the poor-is the largest item in many state budgets, R. Bovbjkrt; \& J. Hot.Ahan, Medicaid in the Reagan Era: Federal PolICY AND STATE Choicks 3 (1982), and in fiscal year 1979, 42.3\% of Medicaid expenditures were devoted to nursing home care. Id. at 45 .

62. Feldblum, supra note 56, at 197-210.

63. Staff of House Subcomm. on Human Services, Select Comm. on Aging, 96th

Conci, 21) Skss., Future: Dirfocitions for Aging Policy: A Human Service Model. 75 (1980). 64. Id. at 66 . 
that those on the winning side of the widening gulf will have greater retirement income or more comprehensive employment-related insurance benefits for the custodial services they will need in old age. But private insurance benefits for such care are rare today, and are too costly ever to be widespread. ${ }^{65}$ For the vast majority of us, particularly women, it is wholly unrealistic to expect that we will retire with sufficient income or insurance to purchase essential supportive services. In short, the New Right and neoconservative visions for the elderly are bleak for all but the very rich.

Contrast with these a variety of feminist visions for caring for the elderly in America. Feminists who embrace the value of differences between men and women would celebrate women's culture and morality of nurture and care. ${ }^{6 B}$ Frail elderly women, and those wage workers and family members who care for them, are largely silent and invisible today. Giving voice to these women's stories through poetry, prose, movies, movements, news and networks is vitally important to enhance the individual and social appreciation of this traditional women's culture. ${ }^{67}$ But, Eisenstein argues, glorification of a "private" world of love, care and nurture will not empower the women who live both in those private worlds and the public worlds of landlords, doctors, nursing homes, Medicaid and Medicare, which are in turn shaped by even larger forces of tax policy, public finance, the national and international flow of capital and labor and more. ${ }^{88}$

Other feminists who argue that women should be "free to choose" the work and roles traditionally reserved for men or for women ${ }^{69}$ fail to appreciate the extent to which the world must be remade in order to make the choice real. That is not to say that liberal legal rights have no role to play in expanding choice. ${ }^{70}$ Rights can increase women's access to tradi-

65. See Somers, Long Term Care for the Elderly and Disabled: A New Health Priority, 307 N. Eng. J. Med. 221 (1982); U.S. General Accounting Office, RPT. No. PAD-80-12, Entering A Nursing Home: Costiy Implications for Medicaid and the Elderly (1979). The cost of health insurance benefits for retirees has become a major source of concern for corporate America. Joseph A. Califano, Jr., former Secretary of Health, Education and Welfare and now a director of the Chrysler Corporation, estimates that the 500 largest industrial corporations currently owe present and future retirees a total of $\$ 2$ trillion, an amount exceeding the $\$ 1.4$ trillion total assets of those companies. Freudenheim, Company Expenses for Retirees Soar, N.Y. Times, Sept. 9, 1985, at 1, col. 1.

66. Jean Elshtain, for example, argues that "familial existence is a presuppositional feature of social existence." J. Elshtain, supra note 20, at 323.

67. For a rich portrait of this world see D. Lessing, The Diary of Jane Sommers (1984).

68. For example, Jean Elshtain defends an understanding of family life that grounds "women in the relations that allow them to stand in criticism of the state and public world." P. 219. Eisenstein asks in response: How is a welfare mother "free to stand against the state" and where does the "privacy" of her family life begin and end? Id.

69. See supra note 23.

70. P. 235. See, e.g., In re Rose Septuagenarian, 126 Misc. 2d 699, 483 N.Y.S.2d 932 (Fam. Ct. 1984) (party's name fictionalized for case publication). In this case, the court ordered support for a 72-year-old woman from the pension fund of her husband who was in a nursing home where his care 
tional male jobs that provide the compensation, insurance and retirement benefits that support a measure of security in old age. Legal rights could increase the value attached to nurturing work through Social Security for homemakers, more adequate welfare programs, support payments at the end of marriage that recognize the value of traditional women's work, and expanded public support for nurturing leaves from wage work. ${ }^{71}$

But the content of legal rights that shape the options and choices available to us is determined through political struggle. Even the most fundamental negative rights, such as the right to speak or to control our bodies free from government constraint, acquire concrete meaning only as people act collectively to claim them. ${ }^{22}$ And negative rights are more easily enforced than affirmative liberties. ${ }^{73}$ Rights that do not impose direct dollar costs on a public budget are easier to protect than those that require public expenditures. ${ }^{74}$ Also, however difficult it is to create and implement public entitlements to material support, a right to a check is more easily affectuated than a right to a caring and supportive human relationship. ${ }^{75}$

Older people, and those who care for them, need material support. But social support for families traditionally has been available only after the "voluntary" services of family and friends are exhausted. ${ }^{78}$ Powerful fiscal

was financed by Medicaid.

The case was litigated as a feminist claim to financial recognition of the contribution that the woman had made to the family through her lifetime. The court found, "to deprive women, and particularly women of petitioner's generation who, in many cases, were denied an equal opportunity to fulfill their potential in the employment market and are, therefore, dependent on their husbands for support, access to their husbands' pension and assets in their later years effectively sentences many of them to tremendous hardship and a complete disruption of their lives at a time when they are extremely vulnerable." 126 Misc. 2d at 702,483 N.Y.S.2d at 934.

$\Lambda$ coalition of feminists and advocates for the elderly persuaded the City of New York to abandon its effort to have the decision overturned, politically or in the courts. Conversation with Ellice Fatoullah, attorney for Rose Septuagenarian, Jan. 22, 1986. See also Sullivan, Nursing Costs Force Elderly to Sue Spouses, N.Y. Times, Mar. 6, 1986, at 1, col. 2.

71. Taub, supra note 55; Feldblum, supra note 56.

72. See D. Kairys, Freedom of Speech, in The Politics of Law: A Progressive Critique (D. Kairys ed. 1982).

73. For a classic statement of this proposition, see I. BERLIN, Two CONCEPTS of LIBERTY (1958).

74. For example, in Dandridge v. Williams, 397 U.S. 471 (1970), the Court upheld a law denying additional welfare payments to families of more than five people despite the obvious adverse impact on family autonomy and compositional choice, which in other contexts the Court has recognized as an aspect of constitutionally protected liberty. See Moore v. City of East Cleveland, 431 U.S. 494 (1977).

75. "Too frequently there is attributed to law and its agents a magical power-a power to do what is far beyond its means. . . The law, so far as specific individual relationships are concerned, is a relatively crude instrument. It may be able to destroy human relationships; but it does not have the power to compel them to develop. It neither has the sensitivity nor the resources to maintain or supervise the ongoing day-10-day happenings between parent and child." J. GoldSTEIN, A. FreUd \&

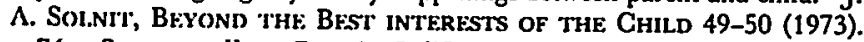

76. See generally tenBroeck, California's Dual System of Family Law: Its Origin, Development, and Present Status (pt. III), 17 SrAN. L. Rev. 614 (1965); Tully, Family Responsibility Laws: An Unwise and Unconstitutional Imposition, 5 FAM. L.Q. 32 (1971). 
and human considerations support this traditional preference and argue for public services that bolster, rather than supplant, voluntary family based care.

All these factors demand collective action, both to generate the political support for the programs that would give content to "choice" for older people and to explore the borders between voluntary family-based services and their exhaustion. Feminist consciousness raising can serve both these functions.

Eisenstein characterizes consciousness raising as the methodology of feminism $^{77}$ and recognizes that through it women develop a sense of collective power "in actual struggle against patriarchal privilege." consciousness raising is a process of self-reflection and action that values women's personal experience and understands that experience as political. ${ }^{78}$ It is "break[ing] out of . . . accustomed ways of responding to domination by acting as if [we] could change things."

Powerful forces deter active feminist consciousness raising. Women who bear the dual burden of family care and undervalued wage labor have too few hours in a day for sleep, much less for attending these sessions. Furthermore, patriarchal culture discourages feminist consciousness raising: In male dominated institutions, women are rewarded for being one of the boys and punished for seeking common cause and understanding with other women. ${ }^{81}$ Yet widespread consciousness raising could ultimately lead to collective action aimed at changing these circumstances.

In the early 1970's consciousness raising played a critical role in the rise of feminism. Thousands of women-mostly young, white and middle class-achieved new understandings of their lives and our world. Work experiences in which they had been denied responsibility were now understood not as personal failures or bad luck but as examples of the pervasive assumption that men necessarily are better at certain jobs. Daily life

77. P. 151

78. P. 154.

79. Although men too could benefit from collective efforts to understand and break out of the constraints that our gendered culture imposes upon them, the process for them is inescapably different. "A white man can afford to be unreflective because he finds himself in a world created in his image. For a woman to be unreflective in a man's world is to be objectified, silenced, and passified-to be rendered an object. The feminist critic, forced to look to nontraditional sources and methods for validation, finds a ground in her own suppressed experience intersubjectively affirmed and confirmed. Thus, it is in women's interests to be self-reflective where it is not necessarily in men's interests." Cole, Getting There: Reflections on Trashing From Feminist Jurisprudence and Critical Theory, 8 HARv. WOMEN's L.J. 59, 81 (1985).

80. Sparer, Fundamental Human Rights, Legal Entitlements, and the Social Struggle: A Friendly Critique of the Critical Legal Studies Movement, 36 STAN. L. REv. 509, 557-58 (1984) (emphasis deleted).

81. R. Kanter, Men and Women of the Corforation 206-42 (1977); Taub, Keeping Women in Their Place: Stereotyping Per se as a Form of Employment Discrimination, 21 B.C.L. REv. 345, 358 (1980). 
provided material for urgent inquiry. Can women in traditionally male jobs express honest emotion without undermining our already fragile credibility? Can we build both commitment and adventure in loving relations? How can men be persuaded to share responsibility for childcare? For many women the consciousness raising experience inspired actions that changed the course of their lives.

Such groups were not the only, or perhaps even the most significant, forms of feminist consciousness raising. The thousands of women who, in the early 1970 's, bore witness to the experience of illegal abortions engaged in a form of consciousness raising that radically transformed the law. ${ }^{82}$ Women who join together to create a community of psychic and material support against rape and domestic violence are engaged in consciousness raising. ${ }^{83}$ In many businesses, unions and schools, women help each other to comprehend their situation in feminist terms and act pursuant to that understanding.

Both older women and the women who care for them, in families and the wage market, require consciousness raising to generate courage and energy to demand needed social support services. The patriarchal vision that the family (i.e., women) cares for the old hinders the development of social responses to the needs of the elderly and disabled, just as it hinders the development of social supports for the care of children. Younger women need consciousness raising to sort out the difference between affirmative desire to help and burdens imposed by a gendered culture and enforced by resentment and guilt. If younger women, raised in an era of sexual liberation, need consciousness raising to figure out what we really want to do with that liberty, then surely a similar process is essential to empower older women to understand their needs for affection, human warmth, and sexuality and to explore how those needs can be met.

Exploring the social meaning of gender, analytically and experientially, is hard work. As social beings, our identities, needs, responsibilities, feelings, pains and pleasures do not spring fully formed from some internal, individual core; rather, they are shaped by social relationships. As feminists we need to struggle openly with these issues. We need to talk with

82. See D. Schulder \& F. Kennedy, Abortion RAP (1971).

83. See V. Randall, Women and Politics (1982); N. MCGlen \& K. O'Connor, Women's Rights: The Struggle for Equaltry in the Nineteenth and Twentieth Centuries (1983).

There are many other forms of consciousness raising that are not explicitly feminist. For example, welfare recipients exploring together the personal and political causes of their problems and acting together on the conviction that their children deserve shoes and coats are engaged in a form of consciousness raising. See G. West, The National Welfare Rights Movement (1982). The civil rights and black power movements concerned not only legal change, but also liberation and consciousness raising-understanding the connections between the personal and political, experiencing less racist ways of being white or black. 
others who share both a basic commitment to the worth of women and the experiences that are common to women. We need consciousness raising because we live in a culture in which great meaning is attached to gender. Such sharing produces insight and builds community, which in turn generates energy and courage for transformative change.

Zillah Eisenstein provides us with a strong statement of the theory of feminism. Analysis is important, but more is needed to move us from theory to action to power. Through mechanisms such as consciousness raising, Eisenstein's theoretical framework can provide the foundation for great social progress toward sexual equality. 